\title{
Recycling and Reuse of Agrotextiles Used in Agricultural Farms
}

\author{
Pooja Bhatt*, Anita Rani, Manisha Gahlot and Vandana Bhandari \\ Department of Clothing and Textiles, College of Home Science, G. B. Pant University of \\ Agriculture and Technology Pantnagar, U. S. Nagar, Uttarakhand, India \\ *Corresponding author
}

Keywords

Agrotextiles,

Recycling, Reuse,

Value addition,

Sustainability

Article Info

Accepted:

12 May 2019

Available Online:

10 June 2019

\section{A B S T R A C T}

The technological advancements have enabled the textile materials find their irreplaceable use in areas like agriculture, horticulture, livestock and fishery. This class of textile materials used in agriculture sector is known as agrotech segment of technical textiles. The textile materials hold a great potential for improvement and enhancement in the quantity and quality of the agricultural products. Govind Ballabh Pant University of Agriculture and Technology, Pantnagar is a leading agricultural university of Uttarakhand as well as country and comprises of different agricultural research farms. The availability of variety of agricultural farms in the university suggests diverse practices being followed therein wherein use of different types of textile materials was expected. The secondary utilization of used, defective and damaged textile materials is a matter of concern in these agricultural research farms. This study was, therefore, planned to develop value added products from the textile materials used in agricultural farms and to assess the consumer acceptability of these products. The products were developed from the used materials which were no longer used for their intended purpose. The used materials were recycled through development of innovative products which ultimately helped to reduce waste generation in the agricultural research farms. The value added products developed from the used textile materials were hanging basket, lampshade, coaster, doormat and wind chime. The recycling and reuse of textile materials for product development helped in establishing ways for consuming used materials in a sustainable manner, i.e. reducing the waste generated after use in agricultural farms.

\section{Introduction}

Agriculture has been the most primary occupation which has spread its roots strongly in the economy of Indian economic sector. The occupation deals with production and price risks due to various internal and external factors. Thus, the solution to these prevailing problems in the agriculture sector was provided through the use of various textile structures. Subramaniam et al., (2009) suggested the fact that in era of modernization the agrotextiles will serve the purpose to boost the high productivity in agriculture sector. Agrotextiles find their application in various areas like agriculture, horticulture, livestock and fishery. It has now become an indispensable part of the agricultural 
practices. Agriculture has close link to textiles as it provides principal functions like crop protection and storage of the produce which in turn plays vital role in increase in productivity of agriculture sector (Agrotextiles, 2017). Furthermore, the uncontrolled and abrupt increase in the human population has stressed the farmers to feed more mouths in the limited amount of land. This called for technological advancement in the development of textile structures to protect the agricultural crops from various concerns. The agrotextiles prevent the soil from drying and helps in increasing the yield.

They improve the quality of the agricultural produce. The use of agrotextiles helps the farmers to minimize the use of harmful pesticides. About 40 percent energy can be saved by the usage of greenhouses (Paul et $a l .$, 2012). The growing population worldwide has imposed serious stress in the agriculture production. Thus, there is need to increase the yield and quality of the agriculture produce. To fulfil the needs of tomorrow the agriculture sector has opted for various technologies to obtain high yield and good quality agro-products. The requirement of fertilizers, pesticides and water is decreased by the efficient use of agrotextiles. The crops attain early maturity and non-seasonal plants can be grown by regulating the temperature through the use of agrotextiles. These textiles also protect the plants from the climatic change and its harmful effect on the plants (Agrawal, 2013). Ajmeri (2016) stated that textiles have found their use in agriculture for thousands of years to protect the plants and animals against adverse environmental conditions. Diversity of textile products are profitably used in agriculture like fishing nets, ropes, shade nets, jute bags, mulch mats, etc. The Indian aggrotech segment is anticipated to grow at a rate of 20 percent to US $\$ 340$ million by 2016-2017 (Agrotech Textile Application in Agriculture, 2016).
Govind Ballabh Pant University of Agriculture and Technology is the leading agricultural university of Uttarakhand and one of the leading agricultural universities of India comprising of different farms wherein variety of crops are grown for research, instructional and commercial purposes. The university has different farms namely, Crop Research Centre, Model Floriculture Centre, Garden Section, Horticulture Research Centre, Vegetable Research Centre, Medicinal Plant Resources and Development Centre, etc. where various crops are cultivated. The agrotextiles were being used in these university farms to enhance the farming techniques in order to improve the quality of the farm produce and to obtain better yield. The variety of crops were grown in various agricultural farms, thus varied agrotextile products were used. Few products were similar owing to similar types of cultivation practice adopted in different crops. All the agrotextiles were not suitable for reuse hence created solid waste. Besides these, defective agrotextiles also contributed to this waste accumulation. The practices adopted in university farm reuse only a fraction of this type of textile waste and that too in agricultural practices. The large chunk of agrotech materials created solid waste which further increased the possibility of reusing or recycling of the materials to reduce the solid waste issues emerging in these farms. The criteria of reusing and recycling the textile materials help to avoid discarding of the materials and thereby using them for development of valuable products. The process of recycling and reusing helps to bring significant environmental and economic benefits by reducing the wastage and providing a means of revenue generation. An efficient way of revenue generation can be achieved through the development of products from agrotextile materials available in the university farms. Recycling and reusing of textiles is regarded to bring huge ecological 
and financial advantages. The agricultural wastes can be used extensively in textile product development which will eventually lead to increased income generation of the people and will be able to provide more employment opportunities (Textiles and Clothing Opportunities for Recycling, 2012). A research study conducted by Siddiqui (2012) suggested that green fashion products can be developed using the principles of sustainability. The waste textile and other waste materials were used for development of green fashion products. The textile related waste was recycled to develop the products having high market demands. Thus, the present study was planned to use the waste developed in the university farms for development of value-added products. This further helped to reduce the amount of waste generated using the principles of recycling and reuse.

\section{Materials and Methods}

The methodology used in the study is as follows.

The study was conducted in five agricultural farms of Govind Ballabh Pant University of Agriculture and Technology, Pantnagar namely, Crop Research Centre, Horticulture Research Centre, Vegetable Research Centre, Medicinal Plant Resources and Development Centre and Fish Seed Hatchery and Instructional Fishery Farm.

\section{Procurement of used textiles from the agricultural farms}

The available used textiles were collected from the university farms to plan the development of value-added products by using them. The various types of textile materials were collected from the farms like storage bags (biaxially oriented polypropylene bags, jute and cotton bags, leno and polyethylene bags), nets (shade net, drag net, fry net and cast net), sheets like polycarbonate sheet, mulch sheet, cloth and polyvinyl chloride tarpaulin, ropes (nylon and jute rope) and other miscellaneous textile materials like bird reflective tapes, plastic pipe, rubber gloves and hatching cloth.

\section{Product planning}

The textile materials were either defective or have lost their intended purpose. The materials collected had different fabric structures like woven, film, knotted, knitted and non-woven. The various structures of the textile materials offered their use in different materials for value addition.

Thus, the value-added household products were planned like, Hanging Basket, Wind Chime, Lampshade, Coasters and Doormat for recycling and reuse of the used textiles available in the selected agricultural farms.

\section{Designing of products}

The designs of the planned products were made by hand and coloured in the colour similar to that of the textiles collected. Five different types of decorative and utility products were designed by the researcher. Five design illustrations were prepared for each planned article. Thus a total of 25 design illustrations were prepared.

\section{Assessment of developed product designs}

The prepared design illustrations of five different planned products were assessed by the panel of judges including 30 members. The panel of judges comprised of 10 teaching faculty members, 10 M.Sc. students and 10 Ph.D. students of College of Home Science. The evaluation of illustrations was done on a five point scale on the basis of overall look and suitability of product to use. The rating 
scale used for evaluation by the panel members is given in Table 1 .

The weighted mean score of each design illustration of the products was calculated and were ranked according their score. I (Excellent)-5, II (Very good)-4, III (Good)-3, IV (Fair)-2, V (Poor)-1

The design illustrations that obtained the highest weighted mean value was ranked I and were selected for each type of planned product to develop the final products.

\section{Cleaning of procured textile materials}

The collected textile materials from the university research farms were used materials thus they needed cleaning. The materials were cleaned according to their fiber composition and technique of construction. The woven textile materials like jute and muslin were machine washed. The non-woven textile materials like shade net, polycarbonate sheet, polyethylene bag, mulch sheet, bird reflective tape, polyethylene sacks and biaxially oriented polypropylene bags were wiped clean by the dampened cloth. The cleaning process removed dust and dirt from the used textile materials procured from the farms. This process helped to enhance the suitability of textile materials for the planned products.

\section{Product preparation}

The products were developed manually in accordance with the selected design illustrations. The products were made from the used textile materials procured from the university farms using the technical specifications given in the illustrations.

The common processes used in making the products involved stitching, pasting and material shaping. Finally, the prepared products were brushed to get finished effect.
Cost calculation and assessment of prepared products

The cost of the prepared products was calculated by adding up the expenses involved in manufacturing the product. The expenses involved the manufacturing cost and cost of materials used in product development used for value addition. The developed products were assessed on the five- point rating scale by sixty respondents (30 M.Sc. students and $30 \mathrm{PhD}$ students) based on six parameters and weighted mean score (WMS). The parameters on which consumer acceptability of the products was assessed included parameters like aesthetic appeal, design innovation, product utility, quality and craftsmanship, suitability of cost and overall appearance of the product.

\section{Results and Discussion}

The findings of the study are given as follows.

$\begin{aligned} & \text { Designing of products and their } \\ & \text { development from collected textile } \\ & \text { materials }\end{aligned}$
from

The design illustrations of five planned products were prepared and are given as Figures 1 to 5. These design illustrations were assessed by the panel of judges constituting of 10 members of teaching staff, 10 M.Sc. students and $10 \mathrm{Ph}$.D. students.

\section{Selection of product from design illustrations}

The weighted mean scores and ranks of the prepared design illustrations were calculated based on the assessment. The data given in Table 2 states that Design 4 of the hanging basket and lampshade obtained the highest weighted mean score and were ranked first while design 1 of coasters and doormat obtained highest weighted mean score in the 
assessment of the final products. Similarly design 5 of the wind chime obtained the highest weighted mean score and was thus selected for development of final products.

The design illustrations obtaining the highest rank were selected for product development. The products developed from used textile materials collected from selected agricultural research farms are given in Figure 6-10.

\section{Cost calculation of the developed products from the used textile materials}

Table 3 states the cost incurred in preparation of products developed from the used textile materials. The raw material charges and production charges of each product were calculated and final cost calculation of products was done.

The estimated cost for hanging basket, wind chime, lampshade, coasters and doormat was calculated as $\square 121, \square 132, \square 168, \square 22$ and $\square 90$ respectively.

Thus the lampshade had highest cost as compared to other developed products while coasters had lowest calculated cost. The high cost of lampshade and hanging basket was due to the cost of electric and metallic wires respectively used in their construction.

Table.1 Weighted mean scores and ranks obtained by the design illustrations of the planned products

\begin{tabular}{|c|c|c|}
\hline Design No. & Weighted Mean Score & Rank \\
\hline Hanging Basket & & \\
\hline 1 & 3.30 & IV \\
\hline 2 & 3.66 & II \\
\hline 3 & 2.73 & $\mathbf{V}$ \\
\hline $4 *$ & 4.56 & I \\
\hline 5 & 3.36 & III \\
\hline 2. & & shade \\
\hline 1 & 3.56 & II \\
\hline 2 & 3.30 & IV \\
\hline 3 & 3.00 & V \\
\hline 4* & 4.06 & I \\
\hline 5 & 3.53 & III \\
\hline 3. & & \\
\hline 1* & 4.20 & I \\
\hline 2 & 3.10 & IV \\
\hline 3 & 3.73 & III \\
\hline 4 & 3.40 & II \\
\hline 5 & 3.40 & II \\
\hline 4. & & \\
\hline 1* & 4.36 & I \\
\hline 2 & 3.33 & III \\
\hline 3 & 4.13 & II \\
\hline 4 & 3.16 & IV \\
\hline 5 & 3.13 & V \\
\hline 5. & & Chime \\
\hline 1 & 3.63 & III \\
\hline 2 & 3.66 & II \\
\hline 3 & 3.53 & IV \\
\hline 4 & 3.40 & V \\
\hline $5 *$ & 4.46 & I \\
\hline
\end{tabular}

$\mathrm{n}=30$

*Selected design illustrations 
Table. 2 Cost incurred in the preparation of products from used textiles of research farms

\begin{tabular}{|c|c|c|c|c|c|c|}
\hline \multirow[t]{2}{*}{ S. No. } & \multirow[t]{2}{*}{ Parameters } & \multicolumn{5}{|c|}{ Cost of products developed from used textile materials ( $\square$ ) } \\
\hline & & $\begin{array}{c}\text { Hanging } \\
\text { Basket }\end{array}$ & $\begin{array}{l}\text { Wind } \\
\text { Chime }\end{array}$ & Lampshade & Coaster & Doormat \\
\hline A. & \multicolumn{6}{|l|}{ Raw Material } \\
\hline 1 & Jute & 6 & 3 & 3 & 3 & 6 \\
\hline 2 & Shade net & 3.7 & 1.5 & 3.7 & - & 3.7 \\
\hline 3 & Polycarbonate sheet & - & 4 & 8 & 8 & 8 \\
\hline 4 & Jute rope & 5 & 5 & - & - & - \\
\hline 5 & Muslin & - & - & 6 & - & - \\
\hline 6 & Mulch sheet & 3 & - & - & - & - \\
\hline \multirow[t]{2}{*}{7} & Leno bag & - & - & - & 1.5 & - \\
\hline & Cast net & - & 6 & - & - & - \\
\hline 8 & $\begin{array}{l}\text { Biaxially oriented } \\
\text { polypropylene bag }\end{array}$ & - & 1 & - & - & - \\
\hline 9 & Bird reflective tape & - & 2 & - & - & - \\
\hline 10 & PVC Pipe & - & 1.5 & - & - & - \\
\hline 11 & Beads & 9 & - & 14 & 1.5 & - \\
\hline 12 & Embroidery thread & 3 & - & 6 & - & 20 \\
\hline 13 & Decorative pipes & - & 15 & - & - & - \\
\hline 14 & Bells & - & 22 & - & - & - \\
\hline 15 & Curtain hook & 5 & - & - & - & - \\
\hline 16 & Copper wire & 40 & - & 40 & - & - \\
\hline 17 & Steel wire & 24 & - & 36 & - & - \\
\hline 18 & Electric wire & - & - & 24 & - & - \\
\hline 19 & Bulb holder & - & - & 5 & - & - \\
\hline 20 & Fevicol & - & 5 & - & 5 & 20 \\
\hline 21 & Sewing thread & 6 & - & 6 & - & - \\
\hline B. & Production Charges & & & & & \\
\hline 1 & $\begin{array}{l}\text { Craftsmanship } \\
\text { charges }\end{array}$ & 16.30 & 16.00 & 16.35 & 9 & 32.30 \\
\hline C. & Total Cost & 121.00 & 132.00 & 168.00 & 22.00 & 90 \\
\hline
\end{tabular}


Table.3 Weighted mean scores of different parameters used for assessment of products developed from used textile materials

\begin{tabular}{|l|c|c|c|c|c|c|}
\hline \multirow{2}{*}{ Product Name } & \multicolumn{6}{|c|}{ Weighted mean score of different parameters } \\
\cline { 2 - 7 } & $\begin{array}{c}\text { Aesthetic } \\
\text { Appeal }\end{array}$ & $\begin{array}{c}\text { Design } \\
\text { Innovation }\end{array}$ & $\begin{array}{c}\text { Product } \\
\text { Utility }\end{array}$ & $\begin{array}{c}\text { Quality and } \\
\text { Craftsmanship }\end{array}$ & $\begin{array}{c}\text { Suitability } \\
\text { of Cost }\end{array}$ & $\begin{array}{c}\text { Overall } \\
\text { Appearance }\end{array}$ \\
\hline Hanging Basket & 4.63 & 4.51 & 4.51 & 4.53 & 4.03 & 4.7 \\
\hline Lampshade & 4.55 & 4.66 & 4.61 & 4.51 & 3.9 & 4.58 \\
\hline Coaster & 4.5 & 4.66 & 4.61 & 4.48 & 4 & 4.43 \\
\hline Doormat & 4.68 & 4.68 & 4.73 & 4.63 & 3.93 & 4.66 \\
\hline Wind Chime & 4.73 & 4.58 & 4.61 & 4.56 & 3.98 & 4.61 \\
\hline
\end{tabular}

Fig.1 Design illustrations of the hanging basket developed from the used textile materials

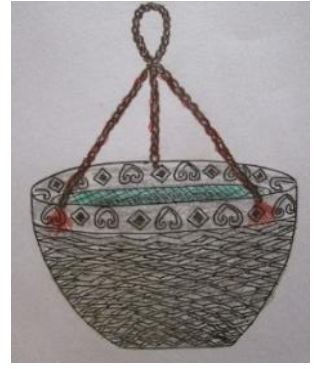

Desian-1

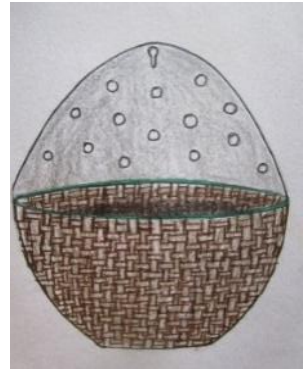

Design-2

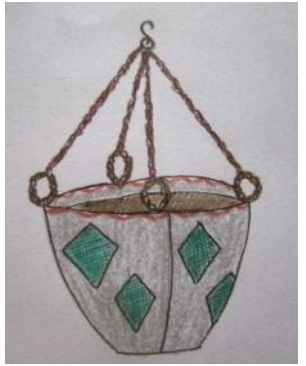

Donian 2

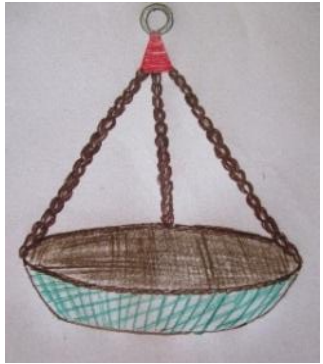

Desian-4

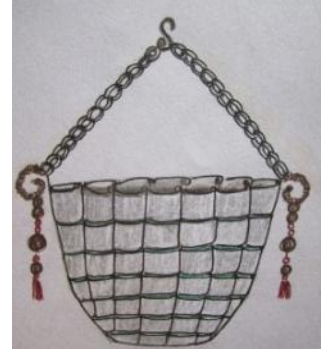

Design-5

Fig.2 Design illustrations of the lampshade developed from the used textile materials
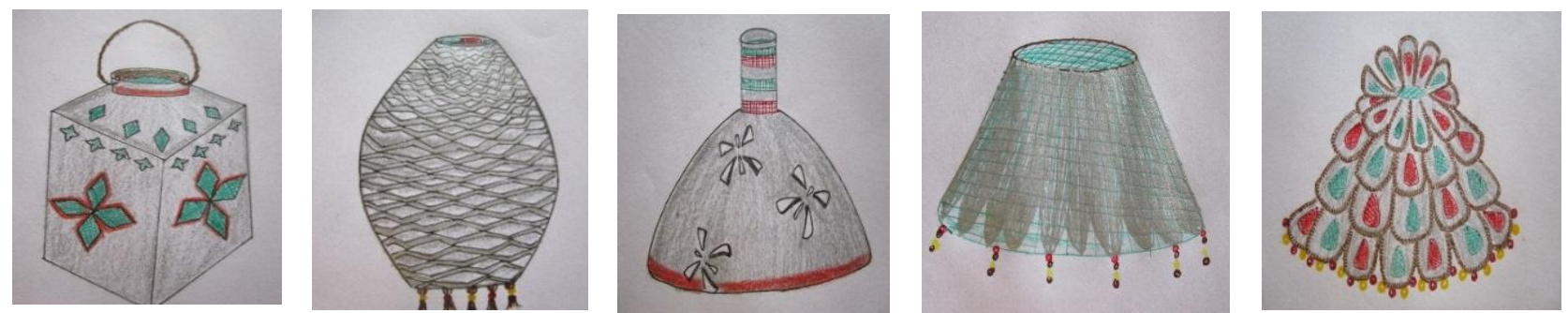

Fig.3 Design illustrations of the coasters developed from the used textile materials

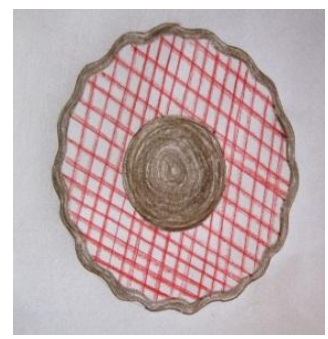

Design-1

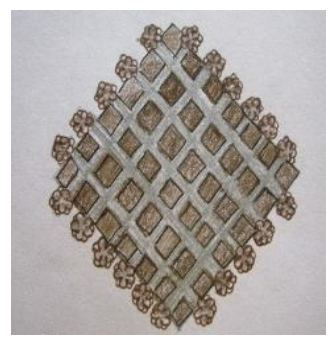

(1)
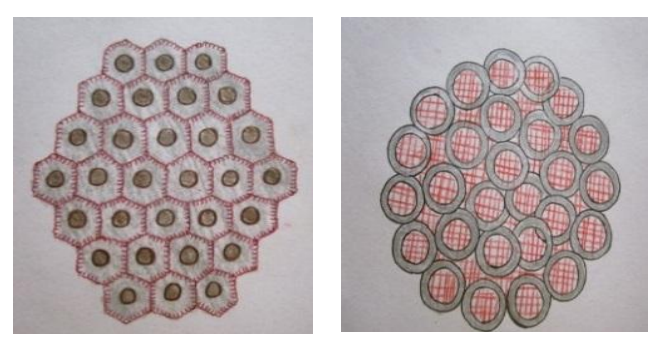

Design-4

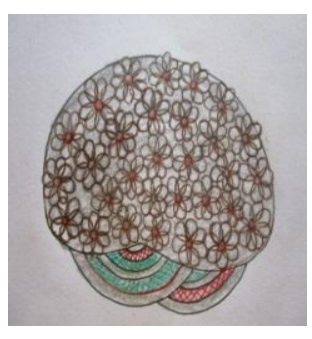

Design-5 
Fig.4 Design illustrations of the doormats developed from the used textile materials
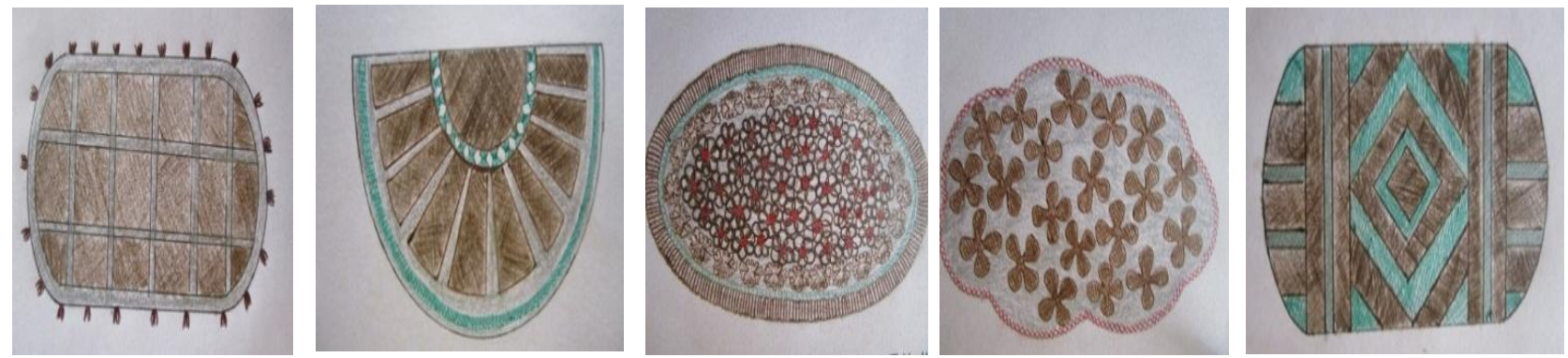

Fig.5 Design illustrations of the wind chimes developed from the used textile materials

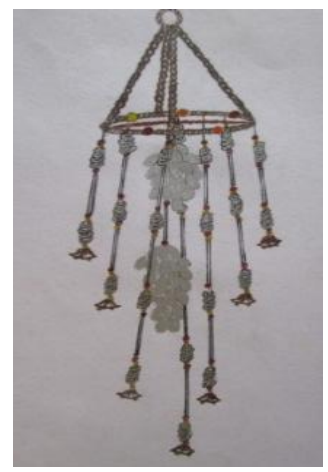

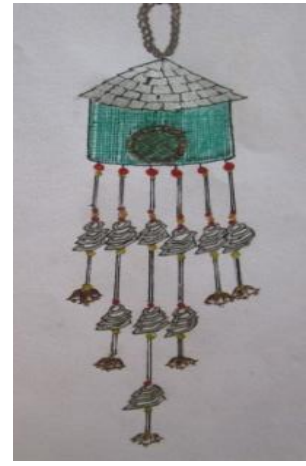

Design-2

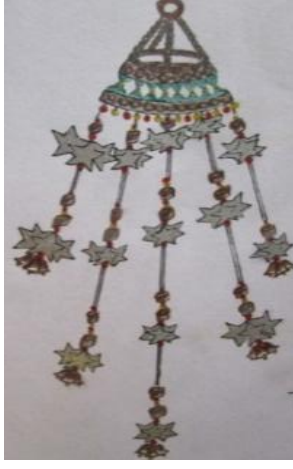

Design-3

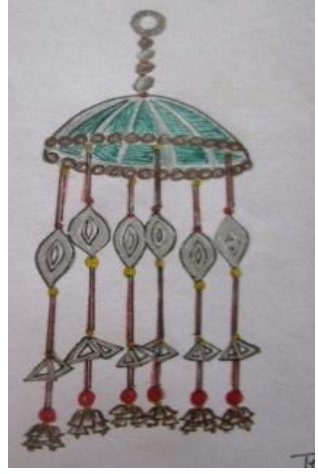

Design-4

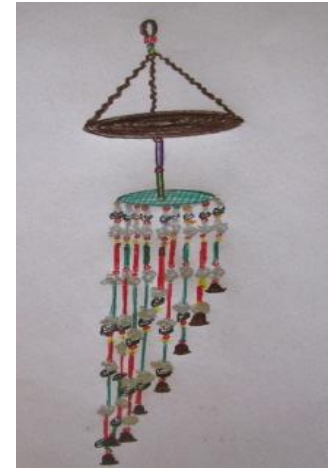

Design-5

Fig. 6-10

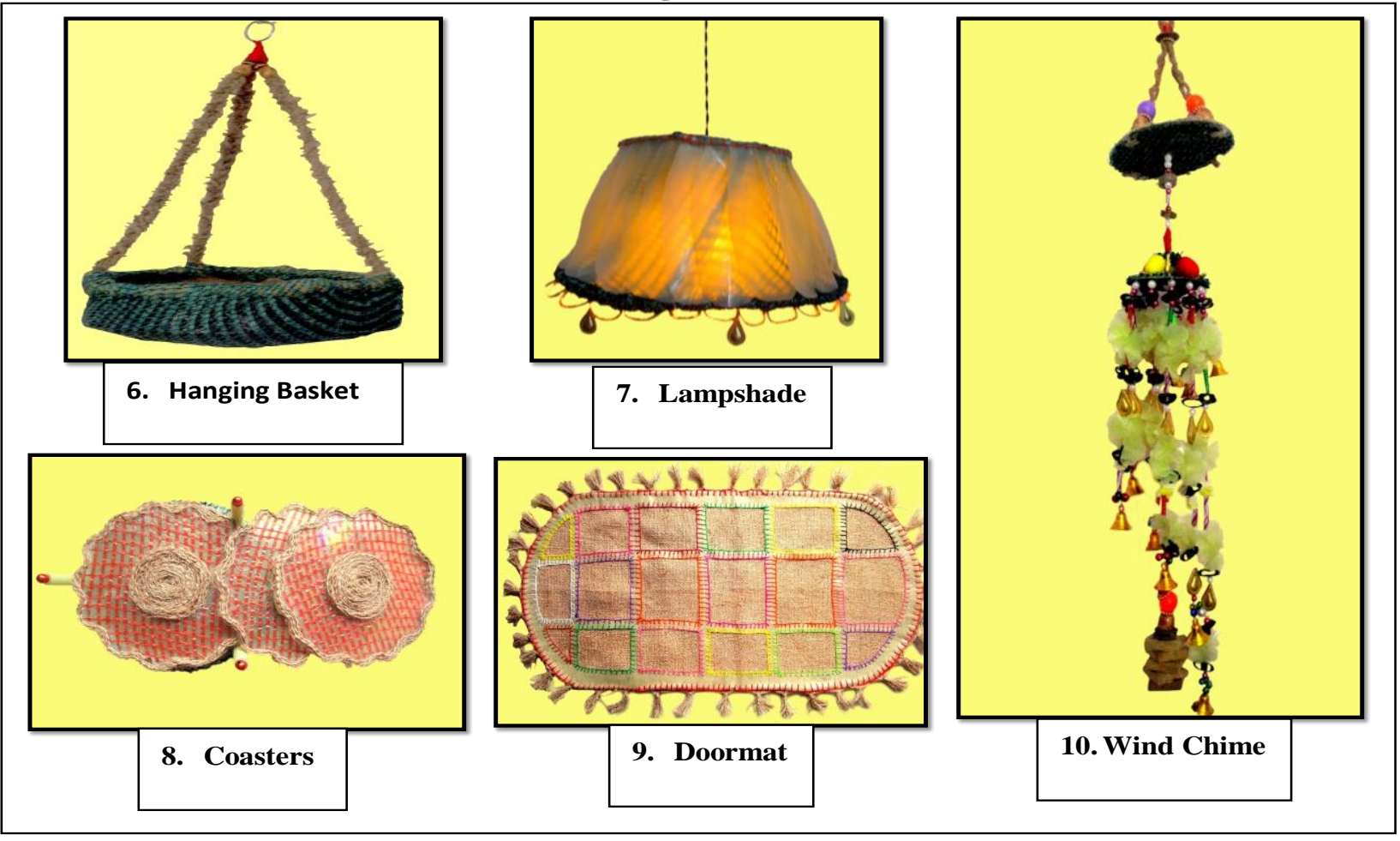


Fig.11 Comparison between different products on the basis of their average WMS obtained in different parameters

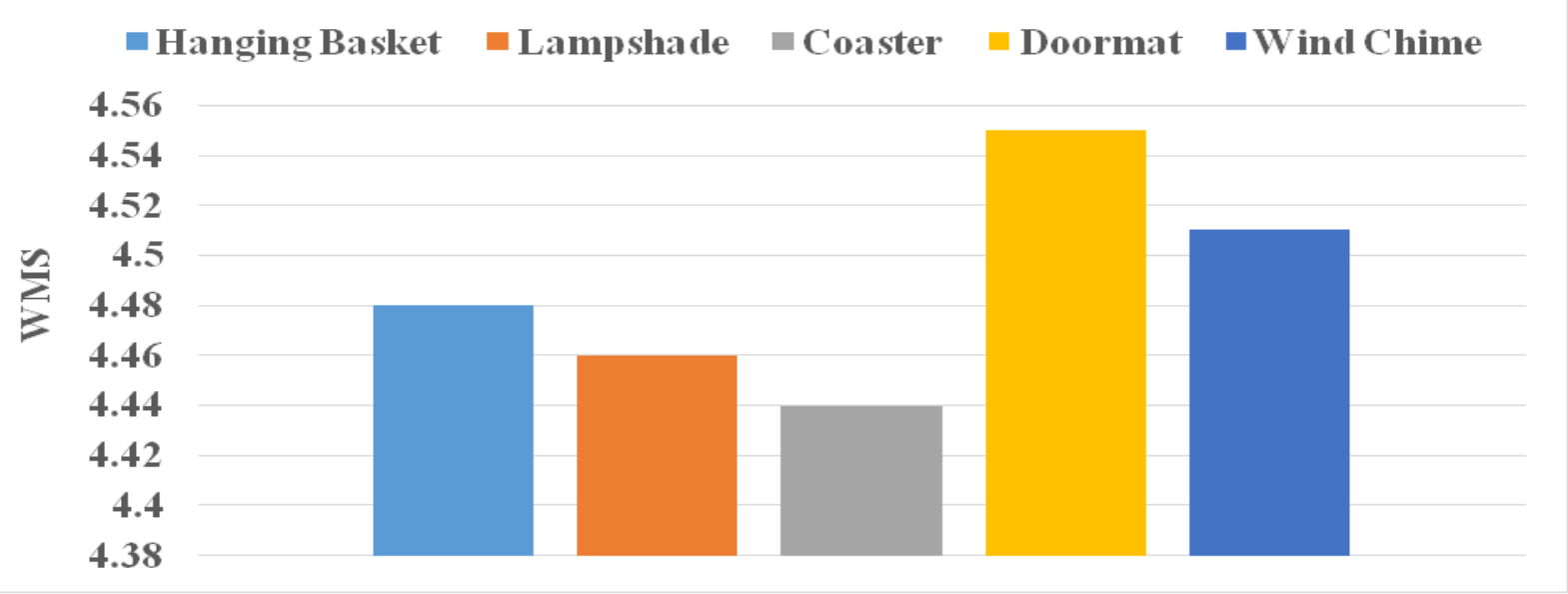

Fig.12 Comparison between different parameters assessed for products on the basis of their obtained average WMS

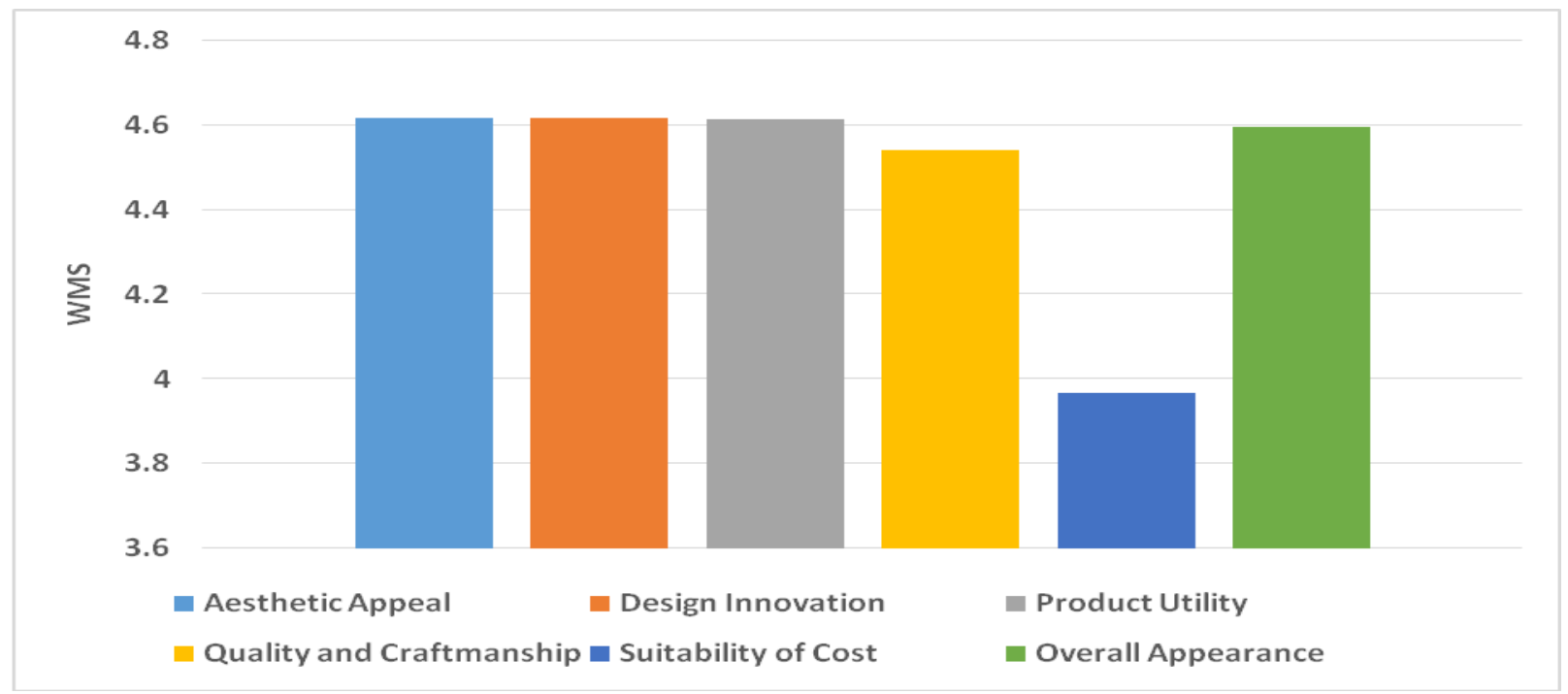

Consumer acceptability of developed products

The weighted mean scores of products for each parameter are given in Table 3. From the data it is clear that doormat obtained the highest weighted mean score and had the highest consumer acceptability level amongst other developed product while coasters had the least consumer acceptability among the developed products. The weighted mean score was highest for wind chime on the aspect of aesthetic appeal (4.73) while weighted mean score was highest for doormat on the aspects like design innovation (4.68), product utility (4.73) and quality and craftsmanship (4.63).

The weighted mean score was highest for hanging basket for aspects like suitability of cost (4.03) and overall appearance of the product (4.7). 
The products were compared for different parameters on the basis of their average WMS obtained for different criteria of each product. Figure 11 depicts the average weighted mean scores obtained by each of the developed product. It is clear from the figure that doormat was widely accepted by the respondents while coasters had comparatively less acceptability. The possible reason for high acceptability of doormat can be the use of doormats in the general household while coasters were not widely used in every household. The materials like wind chime, hanging basket and lampshades had good acceptability as they were utility articles with good aesthetic appeal. It is apparent from the Figure 12 that the aesthetic parameter obtained highest average weighted mean score while the suitability of cost obtained least average weighted mean score.

The possible reason stated for high acceptability was that the products developed were innovative and aesthetically appealing but the cost of the products were considered high. The products were developed from used textile materials which made the respondents believe the cost of the products to be comparatively high. The figure clearly shows that the products developed from used textile materials procured from the agricultural research farms had good acceptability among the respondents and they would prefer to buy them when available in the market.

In conclusion, the used, defective and damaged textile materials were collected from the university research farms. These materials collected were reused or recycled for development for the household utility items like lampshade, doormat, wind chime, coasters and hanging basket. This gives an advantage of utilization of used resources for social and economic benefits. The product development from the used materials fulfills the aspects of sustainability i.e. reduce, reuse and recycle. The used materials are reused or recycled to develop innovative products which ultimately help to reduce the waste generation. It also carves a path to generate a source of income and supports empowerment. Thus, it would be useful to develop products from the agrotextile materials which will surely cut down the amount of textile material supposed to be disposed off.

\section{Acknowledgement}

The authors are thankful to Department of Clothing \& Textiles and staff of agricultural research farms of G. B. Pant University of Agriculture and Technology, Pantnagar for providing research facilities and information regarding the subject matter.

\section{References}

Agrawal, K. S. 2013. Application of textile in agriculture. International Journal of Advance Research in Science and Engineering. 2(7): 9-18.

Agrotech Textile Application in Agriculture. 2016. https://vibrantgujarat.com/ writereaddata/images/pdf/projectprofiles/agrotech-textile-application-inagriculture.pdf. Retrieved on 14 January, 2017.

Agrotextiles. 2017. http://technotexindia.in/agrotextiles.html. Retrieved on 2 January, 2017.

Ajmeri, J. 2016. ed. Kellie, G. Advances in Technical Nonwovens: Development in non-wovens as agrotextiles. Chicago. Woodhead Publishing. pp. 48-69.

Annacchino, A. and Elsevier, H. 2003. New Product Development, From Initial Idea to Product Management. Elsevier Publications. pp. 88-108.

Beaty, C. 2013. An Introduction to The Three R's of Sustainability. www.wildlifehc. org/ an-introduction-to-the-three-rs-of- 
sustainability. Retrieved on 4 April 2017.

Bhasin, H. 2016. Product. www.marketing91.com/what-isproduct. Retrieved on 22 March 2017.

Bloch, P. 1995. Product Design and Consumer Response. Journal of Marketing. 59(1): 16-29.

Chait, J. 2017. Value addition. https://www.thebalance.com/valueadded-products-definition-2538297. Retrieved on 10 June, 2017.

Choi, W. 2005. New Product Development and its Application in Textiles. Journal of Textile and Apparel, Technology and Management. 4(4): 1-26.

Debnath, S. 2014. Roadmap to Sustainable Textiles and Clothing. www.springer.com/ chapter/10.1007/978-981-287-0650_10. Retrieved on 3 January, 2017.

Fisher, G. 2013. Agrotextiles. www.innovationintextiles.com/newagrotextile-report. Retrieved on 28 February, 2017.

Five Core Principles of Sustainability.2017. wikip2pfoundation.net/Five_Core_ Principles_of_Sustainability. Retrieved on 29 April, 2017.

Gopalakrishnan, D. 2012. Agrotextiles- A Rising Wave. http://kiev.all.biz/en/ agrofabric-agrotextiles- agrojutexczech-republic-g11624340\#.

WH2aSVN97IX. Retrieved on 15 January, 2017.

Paul, P.; Sanyal, P. and Gon, D. 2012. Application of natural fibres in agrotextiles.

http://www.indiantextilejournal.com/arti cles/FAdetails.asp?id=4709. Retrieved on 16 March, 2017.

Professional Approach to Product Development, 2017. www.rqriley.com/pro-dev.htm. Retrieved on 2 March, 2017.

Reduce, Reuse, Recycle. 2017. Reduce, Reuse, Recycle: Common and Creative Tips and Ideas. www.sustainablebabysteps.com/reducereuse-recycle.html. Retrieved on 4 April, 2017.

Siddiqui, W. 2012. Green fashion-issue awareness and product development. Thesis, MSc. G.B. Pant University of Agriculture and Technology, Pantnagar. Subramaniam, V.; Poongodi, R.G. and Veena, V. 2009. Agrotextiles: Production, properties and potential. http://www.indiantextilejournal.com/arti cles/ FAdetails.asp?id=1999. Retrieved on 8 March, 2017.

Sustainabilty. 2017. www.thewink.org/ sustain/glossary/sustainability.html. Retrieved on 4 April, 2017.

Textiles and clothing opportunities for recycling. 2017. http://www.evancarmichael. com/Marketing/3924/Reusing-wastetextile-and-clothing-products-in-a-waywhich-avoids-throwing-the-itemsaway.html. Retrieved on 2 January, 2017.

\section{How to cite this article:}

Pooja Bhatt, Anita Rani, Manisha Gahlot and Vandana Bhandari. 2019. Recycling and Reuse of Agrotextiles Used in Agricultural Farms. Int.J.Curr.Microbiol.App.Sci. 8(06): 1566-1576. doi: https://doi.org/10.20546/ijcmas.2019.806.188 